\section{Defence sanctions open doors for India's private companies}

[NEW DELHI] The Indian government announced last week that it will allow private companies to become more closely involved in defence research and development, as well as in the production of military hardware.

The move is being widely interpreted as an attempt by the government to overcome the impact of the sanctions announced by the Clinton administration in the aftermath of the nuclear tests conducted by India last month (see Nature 393, 197; 1998).

According to defence minister George Fernandez, some of the nation's secret defence laboratories will be opened to the private sector, and private companies have been invited to become 'partners' in defence research. At present, the private sector has no role in defence research, and almost all of India's military hardware is produced in factories which are under the control of the defence ministry.

Fernandez announced the new policy at a meeting with leading industrial companies that are members of the confederation of Indian industry (CII). Rajesh Shah, CII's president, assured the government that the private sector would be able to play a big part in defence projects.

In spite of official claims that the US sanctions will not harm India's defence efforts, defence scientists privately admit that most of the projects run by the Defence Research Development Organization (DRDO) involve many imported components to which India may no longer have access.

It is also feared that the sanctions may hamper DRDO's plan to increase the indigenous content of military hardware to 70 per cent by the year 2005, from its current 30 per cent. The only way of achieving this goal now is by increasing the involvement of Indian industry.

Besides working with DRDO as partners in research, private companies will, under the new policy, be allowed access to technology developed by DRDO with potential civilian use. According to DRDO chief Abdul Kalam, for example, techniques for making carbon composite material used in missile nose cones will be available to a company that wants to produce this material to make lightweight calipers for polio victims.

A special committee will choose the DRDO technologies with potential civilian applications. Other committees will identify research areas for partnership between DRDO and CII companies, and possible joint ventures for producing and exporting military hardware.

K. S. Jayaraman

\title{
Russian miners add weight to protests by scientists
}

[MOSCOW] Researchers from branches of the Russian Academy of Sciences throughout the country held a mass protest march in Moscow last week to complain about the continued deterioration in their working conditions.

The protest followed the news that, after an earlier decision by the government to reduce funding for science next year by 27 per cent, it has now been decided that science will get only two-thirds of this reduced financing because of the country's worsening economic situation.

"Our leaders do not seem to understand that Russia cannot afford to allow its science to be destroyed, and should pass the steeringwheel to others," says Viktor Kalinushkin, a physicist and chairman of the Moscow council of the Academy of Sciences' trade union.

The protest march brought together representatives of all the scientific centres near Moscow, as well as others from 20 research centres throughout the country. It began on 15 June in unusually high early summer temperatures at the Pushchino biological centre, 100 kilometres from Moscow.

During the march, one group of scientists briefly blocked the Simferopol highwayleading to the capital from the south-west, while another group blocked the Kaluzhskoe highway near Troitsk scientific centre, 30 kilometres from Moscow.

The scientists reached the Institute of Medicinal Plants in the suburbs of Moscow three days after setting out, and held a short meeting before boarding a bus to the city centre.

"Most Russian scientists consider the president and the government unable to alter the present political course, which turns Russia into a backward country of colonialtype economy," said Kalinushkin in a television interview.

"If they are just going to sell off the country's natural resources, then they do not need high technologies, to say nothing of fundamental science. This explains why President Boris Yeltsin and his newly appointed prime minister Sergey Kirichenko are breaking their promises to scientists so easily."

Originally, the trade union had planned to hold a meeting at Gagarin Square, near the academy's presidium building, with 3,000 participants. But the city authorities refused permission, arguing that it would interfere with traffic.

After the scientists had rejected alternative sites, it was suggested that they should hold their meeting near parliament, provided there were no objections from the miners, who had been holding a protest there for several days.

The government may have been hoping that the miners would show little desire to cooperate with the scientists, whose previous complaints have been purely economic. But the two groups found themselves united in demands to change the regime, and the miners agreed to a joint protest.

A decision by the authorities to reduce the number of those allowed to take part in the protest to a few hundreds meant that the scientists were restricted to five or six representatives from each institute.

Vladimir Strakhov, director of the Earth Physics Institute and full member of the academy, was the only scientist of such high rank to take part in the protest. Eighteen months ago, he went on hunger strikes to protest against scientists not being paid (see Nature 383, 563; 1996).

The joint action of the miners and scientists provided a unique demonstration of the Marxist commitment to "the union of physical and mental labour". For the first time in Russian history, the two groups seemed united behind slogans that were virtually identical - which could lead to some of the most dangerous protests since the beginning of 'perestroika'.

CarlLevitin

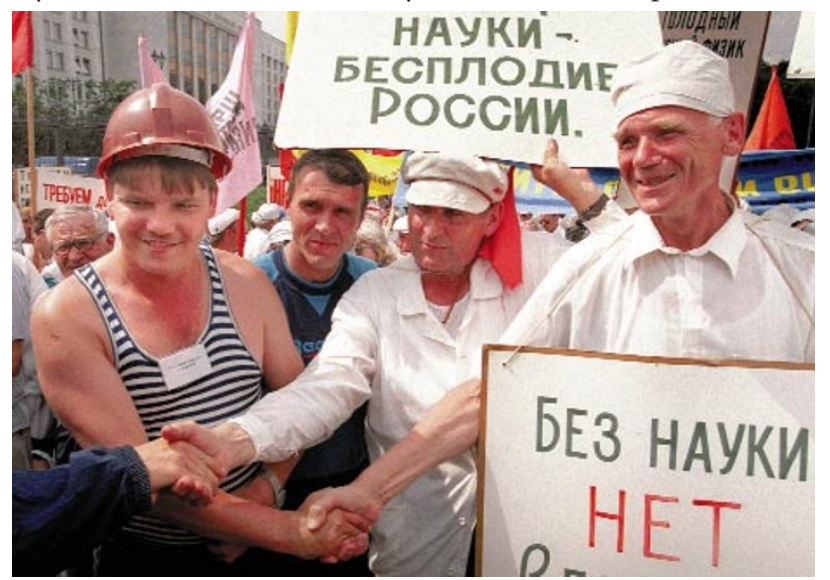

Fraternity: scientists protesting over further cuts in research budgets greet striking miners at a protest outside the Russian White House. Placards read "Castration of science means impotence for Russia." 